\title{
Pico, Plato, and Albert the Great: The Testimony and Evaluation of Agostino Nifo
}

\author{
EDWARD P. MAHONEY
}

Giovanni Pico della Mirandola (1463-1494) is without doubt one of the most intriguing figures of the Italian Renaissance. It is thus no surprise that he has attracted the attention of many modern scholars. By reason of the varied interests that are reflected in his writings, contrasting interpretations of Pico have been proposed. ${ }^{1}$ Our purpose here is not to present a new and different picture of Pico but, rather, to offer a contribution to one fruitful area of research pursued by some recent historians of philosophy, namely, Pico's debt to, and

1. For general presentations of Pico's life and thought, see the classic study of Eugenio Garin, Giovanni Pico della Mirandola: Vita e dottrina (Florence: F. Le Monnier, 1937); Garin's magisterial Storia della filosofia italiana, 2d ed. (Turin: G. Einaudi 1966), 1:458-495. Among more recent general accounts are Pierre-Marie Cordier, Jean Pic de la Mirandole (Paris: Debresse, 1958); Engelbert Monnerjahn, Giovanni Pico della Mirandola (Wiesbaden: F. Steiner, 1960); Paul Oskar Kristeller, Eight Philosophers of the Italian Renaissance (Stanford: Stanford University Press, 1964), pp. 54-71; Giovanni di Napoli, Giovanni Pico della Mirandola e la problematica dottrinale del suo tempo (Rome: Desclée, 1965); Charles Trinkaus, In Our Image and Likeness (Chicago: University of Chicago Press, 1970), 2:505-526; and Henri de Lubac, Pic de la Mirandole: Etudes et discussions (Paris: Aubier Montaigne, 1974). 
use of, medieval philosophy in his overall philosophical enterprise. ${ }^{2}$ Of particular concern will be the influence of Albert the Great on Pico, which can be established by a connection that has apparently not been noticed by Pico's historians. A rather unusual interpretation that Pico offered of Plato's notion of the soul will be shown to have already been set forth by Albert the Great, one of Pico's favorite medieval sources. ${ }^{3}$ It will be argued that Pico drew this interpretation from Albert, possibly having forgotten its source. The plausibility of this thesis obviously rests in part on the ground of Pico's general interest in Albert. ${ }^{4}$ This use of Albert by Pico is but further evidence of a tradition of "Albertism" to be found in Italy during the late Middle Ages and the Renaissance. ${ }^{5}$

2. See in particular the pioneering study of Avery Dulles, Princeps Concordiae (Cambridge, Mass.: Harvard University Press, 1941), and also the more recent study of Paul Oskar Kristeller, "Giovanni Pico della Mirandola and His Sources," in L'opera e il pensiero di Giovanni Pico della Mirandola nella storia dell'umanesimo (Florence: Ist. naz. di studi sul Rinascimento, 1965), 1:35-133. See also Innocenzo Colosio, "Pico della Mirandola e la scolastica," in Studi Pichiani (Modena, 1965), pp. 41-57.

3. Albert is listed by Pico in his celebrated Oration on the Dignity of Man among the medieval Christians who engaged in philosophy. The others mentioned are Thomas Aquinas, Duns Scotus, Giles of Rome, Henry of Ghent, and Francis Meyronnes. Albert is distinguished in that his works contain something that is "ancient, copious, and great" (priscum, amplum et grande). See De hominis dignitate, Heptaplus, De ente et uno, ed. Eugenio Garin, (Florence: Vallecchi, 1942), p. 140. It should also be noted that Albert is placed first among the Latins represented in Pico's Conclusiones sive theses DCCCC, ed. Bohdan Kieszkowski (Geneva: Droz, 1973), pp. 27-28.

4. This interest is indicated by the works of Albert that were found in Pico's library: see Pearl Kibre, The Library of Pico della Mirandola (New York: Columbia University Press, 1936), pp. 61-62, 70, and 113. Albert's commentaries on Aristotle and other works like the De homine appear in the inventory published by Kibre (pp. 119-297). Especially significant is the presence of Albert's Metaphysica (pp. 147-148, entry no. 196).

5. For discussions regarding Albert's influence in Italy in the late Middle Ages and the Renaissance, see Martin Grabmann, Mittelalterliches Geistesleben 2 (Munich: Max Hüber, 1936), pp. 396-400 and 407-408; Edward P. Mahoney, "Albert the Great and the Studio Patavino in the Late Fifteenth and Early Sixteenth Centuries," in Albertus Magnus and the Sciences, ed. James A. Weisheipl (Toronto: PIMS, 1980), pp. 537563; Graziella Federici Vescovini, "Su alcune testimonianze dell'influenza di Alberto Magno come 'metaphysico', scienziato e 'astrologo' nella filosofia padovana del cadere del secolo XV: Angelo di Fossombrone e Biagio Pelacani da Parma," in Albert der Grosse: Seine Zeit, sein Werk, seine Wirkung, ed. Albert Zimmermann, Miscellanea Mediaevalia 14 (Berlin and New York: W. de Gruyter, 1981), pp. 155-176; Gregorio 
In his commentary on Calo ben Calonymus's fourteenth-century Latin translation of Averroës's Tahafut al-Tahafut, known as the Destructio destructionum, ${ }^{6}$ Agostino Nifo (c. 1470-1538) 7 sketches out three basic positions on the soul, namely, $(a)$ the position that was attributed to Plato by Giovanni Pico della Mirandola in a conversation that he had with Nifo, $(b)$ the position of Aristotle and Averroës, and (c) the position that is held by Christian faith and that Nifo believes to be Plato's real position.

The first two positions ( $a$ and $b$ ) maintain that the soul is one in number for all humans both before its entry into the human body and also after it departs from the body, but it is multiplied while it is in the body. These two positions differ inasmuch as position $a$, attributed to Plato, states that a real multiplication of souls is brought about (multiplicatio fiat secundum rem) as long as the soul is in the body, whereas position $b$, of Aristotle and Averroës, maintains that the single intellect is "multiplied" according to the many relationships (secundum respectus et habitudines multas) which exist only in human bodies and not in the single intellect itself. That is to say, there is no real multiplication of the separate intellect or intellective soul for Aristotle and Averroës. Nifo makes clear that however one understands position $b$, it is false and not to be believed.

Position $b$, that is, that of Aristotle and Averroës as he understands them, Nifo rejects. But he does not do so on the basis of

Piaia, "La genèse de l'interprétation historique et philosophique d'Albert le Grand (XVe-XVIIle siècles)," in Albert der Grosse, ed. Zimmermann, pp. 237-255; Luigi Olivieri, Pietro d'Abano e il pensiero neolatino (Padua: Antenore, 1988).

6. On this translation and Nifo's edition, see Moritz Steinschneider, Die hebräischen Übersetzungen des Mittelalters und die Jüden als Dolmetscher (Berlin: Bibliographische Bureau, 1893), pp. 330-333; Maurice Bouyges, ed., Averroès: Tahafot al-Tahafot, Bibliotheca Arabica Scholasticorum, serie arabe 3 (Beirut: Imprimerie Catholique, 1930), pp. xxiii-xxvi. The work was translated again in the sixteenth century by another Calo Calonymos, namely, Calonymos ben David of Naples. See Beatrice A. Zedler, ed., Averroes' "Destructio Destructionum Philosophiae Algazelis" in the Latin Version of Calo Calonymos (Milwaukee: Marquette University Press, 1961), pp. 24-31.

7. On Nifo's life and works, see Edward P. Mahoney, "Agostino Nifo," Dictionary of Scientific Biography 10:122-124; Pietro Borraro, "Agostino Nifo, umanista e filosofo," Archivio storico di terra di lavoro 5 (1977): 169-192. For his years at Padua, see Bruno Nardi, Saggi sull'aristotelismo padovano dal secolo XIV al XVI (Florence: Olschki, 1958); Edward P. Mahoney, “A Note on Agostino Nifo," Philological Quarterly 50 (1971): $125-132$. 
any philosophical refutation, for at this point in his philosophical development he believed that reason was incapable of finding such a refutation. Instead he invokes the authority of the "Christian law" (lex nostra), that is, the doctrinal teaching of the church, which maintains that human souls remain after death as individual soulsthose souls which did good are glorified while some are damned, namely, those which sinned. Nifo adds that he thinks that this view, namely, that individual souls survive death, is also the opinion of Plato and Avicebron. Nonetheless, Nifo is careful to add that the famed opinion of Plato can still be explained according to the first interpretation $(a)$. Indeed Nifo reveals that one of his contemporaries believed that the first position $(a)$ was Plato's own mind. 8

Earlier in his commentary Nifo had in fact indicated that in a conversation with him Giovanni Pico della Mirandola (comes Mirandulus) had attributed just such a theory to Plato. The conversation apparently took place in late May 1494, while the two young philosophers were traveling from Ferrara, where the young Thomas de Vio (1468-1534), later to become Cardinal Cajetan, ${ }^{9}$ had given a public

8. Agostino Nifo Expositio, in Destructiones destructionum Averroys cum Augustini Niphi de Suessa expositione 4 doubt 7 (Venice, 1497), fol. 65ra: "Debes scire quod illa prima opinio de anima, dicens quod anima est una ante adventum ad corpus et post, et dum est in corpore multiplicatur, potest intelligi duobus modis. Uno modo quod ista multiplicatio fiat secundum rem ipsi animae ita quod ipsa anima dum corpori unitur est multa secundum rem, dum separatur uniatur secundum rem et fiant omnes una. Et haec videtur opinio attribuita Platoni, ut fuit visum in prima disputatione. Alio modo potest intelligi quod anima prout est intellectus est unus numero, prout intelligitur in corpore efficitur multa secundum respectus et habitudines multas, non quidem respectibus et habitudinibus inhaerentibus ipsi intellectui, sed corporibus in quibus unitur. Et haec est opinio Aristotelis et Averrois ut recitatum fuit in prima disputatione in solutione 23. Sed quomodocumque intelligitur est falsa et non est credibilis. Immo lex nostra ponit quod animae mortuorum remanent post et quaedam in gloria, ut illae quae fecerunt bene, aliquae damnatae, ut illae quae peccaverunt. Et haec est opinio Avicebronis et Platonis, ut puto. Potest tamen illa opinio famosa secundum primum intellectum adhuc exponi, quoniam unus vir coetaneus meus volebat illam esse mentem Platonis." This volume formed a unit with Nifo's edition of Aristotle and Averroës published in 1495-1496. See Gesamtkatalog der Wiegendrücken 2 (Leipzig: Hiersemann, 1926), no. 2340, cols. 572-574; 3 (1928), no. 3106, cols. 216-217.

9. Cajetan's years at Padua remain to be studied in greater depth. On his life and works, see M.-J. Congar, "Bio-bibliographie de Cajetan," Revue thomiste 39 (19341935): 3-49. 
disputation at the general chapter of the Dominicans, in the direction of Bologna, where they were to attend the general chapter of the Franciscans and a public disputation by Alessandro Achillini (14631512). ${ }^{10}$ The text that served as the occasion of Nifo's recounting his conversation with Pico is a passage in al-Ghazzali's Tahafut al Falasafah, that is, the Incoherence of the Philosophers.

Al-Ghazzali presents as Plato's view-which he himself rejects as erroneous-that the one and eternal (una et antiqua) soul is divisible (divisibilis) according to the division of bodies but returns (redit) to its source (radix) and is made one (unitur) when it separates itself from individual human bodies. ${ }^{11}$ In his commentary, Nifo confesses that he considered this passage for a long time but always remained in doubt as to its meaning. He then goes on to relate the explication of Plato that Pico had offered while they were traveling together to Bologna. Plato's position is supposedly that there is one Idea of souls (una idea animarum), which is related to those souls like the pieces of wood in the arches and vaults of houses. According to Pico, just as these pieces of wood that are placed beneath (subterposita) the stones strung together (incalcinatis) in the manner of an arch leave their "trace" (vestigium) when they are removed after the stones have dried-this trace is called the "vault" (volta) or "arch" (arcus) so too does the single Idea of all souls (una idea numero omnium animarum) leave its "shadow" (umbra) or "trace" (vestigium), which is called "soul." This occurs when bodies have been formed by the soul's generative power (virtus genitiva) and it withdraws from them. Pico takes Isaac Israeli's statement that the soul is produced in the shadow

10. For an account and dating of this incident, see Nardi, Saggi, p. 319 and also pp. 227-228. However, di Napoli (Giovanni Pico, pp. 49-50) has argued that the incident must have occurred in the academic year 1485-1486; he does not note that Nifo would have been sixteen years old at the time. It is noteworthy that Nifo relates that he himself disputed a particular point at Bologna. See Expositio Destructio destructionum 1 doubt 11 , fol. $13 \mathrm{vb}$.

11. Text of al-Ghazzali in Destructiones destructionum 1 doubt 8, fol. 9ra: "Ait Algazel. Et si forte aliquis diceret quod opinio Platonis est vera, videlicet quod anima est una et antiqua et dividitur divisione corporum et in corporea separatione redit ad suam radicem et unitur, nos vero respondemus quod haec opinio est absurdior opinionibus animae et contra intellectus sententiam." For the English translation of the Arabic text, see Averroes' Tahafut al-Tahafut, trans. Simon Van Den Bergh (London: Trustees of the E. J. W. Gibb Memorial, 1969), 1:15. 
(umbra) of the Intelligence to mean that the soul is produced in the shadow of the one Idea (in umbra ideae) of souls. The soul itself, that is, the individual human soul, is thus for Plato the "reverberation" (resultatio) or "trace" (vestigium) of that Idea, just as the Idea itself is the "nursery" (seminarium) or "root" (radix) of souls. Pico apparently understood Plato to be referring to this single Idea of souls when he said that souls return to their nursery (seminarium) at the time that they abandon their bodies. The explanation is that souls are no longer "traces" (vestigia) after they flow into their nursery. Nifo sums up Pico's interpretation of Plato by saying that Plato thus maintained that all souls are one in their source (radix), although they are also somehow many in their "beginnings" (originaliter). This interpretation of Plato's position Nifo considers to be very much in agreement with what al-Ghazzali and Averroës are saying here. Indeed, Nifo takes alGhazzali's attempt to prove the multiplicity of souls in the lines that follow to be a sign that Plato thought the soul to be one in number. ${ }^{12}$

Nifo's own reaction to Pico's interpretation of Plato appears to be twofold. First of all, he attempts to find some similarity between the notion of a single Idea of all souls and what Themistius, a "solemn

12. Nifo Expositio Destructio destructionum 1 doubt 8, fol. 9rb: "Ego diu consideravi verbum istud, et cum inspexi hoc semper steti in dubio et petii declarationem illius. Dixit comes Mirandulanus corona nostrae aetatis in corbula me petente Bononiam quod opinio Platonis ponit unam ideam animarum quae se habet respectu animarum sicut ligna in voltis et arcubus domorum. Dicebat enim quod, sicut ligna illa subterposita lapidibus incalcinatis ad modum arcus post exsiccationem illorum remota dimittunt vestigium eorum, quod vocatur volta seu arcus, sic est una idea numero omnium animarum, quae cum corpora formantur a virtute genitiva egreditur illa et recedit dimittitque eius umbram seu vestigium eius, quod anima vocatur. Et sic dixit dictum Isaac Israelitae intelligi, scilicet quando dicit animam esse productam in umbra, intelligitur idest ideae. Ista ergo resultatio seu vestigium apud Platonem anima erat, et ideo illa ideam seminarium seu radicem dicebat. Et tunc dixit Plato quod quando animae desinunt corpora, tunc redeunt ad earum seminarium in tantum quod vestigia illa, quae animae erant, amplius non sunt post redundant in suum seminarium, ut dicit. Et hanc opinionem dixit esse Platonis ille vir. Et ita Plato posuit omnes animas esse unam in radice, plures autem originaliter. Et sic huic multum consonat series verborum Algazelis et Averrois, quoniam nititur Algazel probare multitudinem animarum in verbis sequentibus, propter quod signum est quod Plato opinabatur unam esse tantum." This passage is reproduced in Garin's edition of Pico's De hominis dignitate, pp. 84-85. On Pico's villa at Corbola, see di Napoli, Giovanni Pico, pp. 227 and 253. 
Platonist" (solemnis Platonicus), supposedly says about Plato according to Averroës. Paraphrasing a crucial passage from book 12 text 18 of Averroës's long commentary on the Metaphysics, Nifo presents Themistius as stating that Plato postulated an Idea of the earth (idea terrae) made from the secondary gods, where Aristotle speaks of the same as composed of the sun and the inclined orb. Nifo adds that it is apparent from the passage and also from his own exposition on that passage that Themistius is talking about an Idea. ${ }^{13}$ And in his early commentary on book 12 of the Metaphysics, Nifo does indeed relate that Themistius proved on behalf of Plato that there had to be Ideas in order to save the notion that animals are generated from putrefaction. ${ }^{14}$ On Nifo's reading, Themistius argued that since such animals are not brought into being by parents, and in particular from a father, they must be produced by their "like" (simile), namely, an Idea. Nifo then connects this "Idea" with the world-soul (anima mundi) that Plato puts forth in the Timaeus, though Nifo admits another interpretation is possible. What is noteworthy is that Nifo considers Themistius himself to agree with Avicenna and Plato that substantial forms come from a being separated from matter. ${ }^{15}$

There are in fact passages in the commentary on the Destructio destructionum in which Nifo groups Themistius together with Avicenna and Plato. In one of these passages, Nifo reviews Plato's conception of the world-soul in the Timaeus, noting that it is simultaneously the soul and the mover of the orbs, an Intelligence placed in that soul by God, and a seed-bearing and vital power infused in matter. He then finds a similar doctrine in the conception of the agent intellect put forth by Themistius in his paraphrases on the De anima. Also supposedly similar is Avicenna's notion of a "giver of forms" (dator formarum ) - called colcodea in Arabic according to Nifo-which is

13. Nifo Expositio Destructio destructionum 1 doubt 8, fol. 9rb: "Huic etiam Themistius solemnis Platonicus, ut narrat Averroes 12 Metaphysicae, commento 18 , concordat dicens quod Plato posuit ideam terrae factam ex diis secundis; Aristoteles autem a sole et orbe declini, ubi loquitur de illa idea, ut apparet ibidem et in expositione mea." Compare Averroës, Commentaria in libros metaphysicorum Aristotelis, in Aristotelis Opera 8 (Venice, 1562), 12 text 18, fol. 304rb. Nifo himself would come to view Themistius as considering the world-soul, not an Idea, to be the source of animation for all souls.

14. Nifo In duodecim metà tà physikà seu metaphysices Aristotelis et Averrois text 13 (Venice, 1505), fol. 8va.

15. Nifo In metaph. text 18 , fols. $11 \mathrm{rb}-12$ va. 
the source of substantial forms in things. ${ }^{16}$ It should be underscored that the assimilation of Plato, Themistius, and Avicenna was inspired to some extent by Averroës himself and also by Albert the Great, and that this assimilation had already been anticipated by Nifo's teacher, Nicoletto Vernia (d. 1499), who also was an acquaintance of Pico's. ${ }^{17}$ Nifo promises to take up in his De intellectu Avicenna's conception of the dator formarum, or colcodea, and Plato's and Themistius's notion of a single soul of all forms and souls. ${ }^{18}$ At this point, Nifo does not seem to distinguish sharply the position of Themistius from that of Plato.

The second aspect of Nifo's reaction to Pico's interpretation was to tell Pico that it was not Plato's own doctrine, as was obvious from the Phaedo. Nifo claims that when he showed Pico the text of the Phaedo, Pico did not contradict it. However, what Nifo himself then presents as Plato's thought surely goes beyond the text of that dialogue. Nifo takes Plato to have held that souls are created by God in a set number and abide in glory in the heavens or the nursery orb

16. Nifo In metaph. 9 doubt 2, fol. 97va-b. See also 11 doubt 1, fol. 107va. On Themistius making the agent intellect to be the cause of all sensible forms in book 1 of his abbreviatio of the De anima, see 7 doubt 3, fol. 86rb. This reference appears to be inspired by Averroës, In metaph. 7 text 31, fol. 181ra. Nifo does not quote Ermolao Barbaro's translation of Themistius. On the term colcodea, see Carlo A. Nallino, Raccolta di scritti editi e inediti (Rome: Insitituto per l'Oriente 1948), 6:261; Bruno Nardi, Studi su Pietro Pomponazzi (Florence: F. Le Monnier, 1965), pp. 234235, n. 1; Harry A. Wolfson, Studies in the History of Philosophy and Religion, ed. Isadore Twersky and George H. Williams (Cambridge, Mass.: Harvard University Press, 1977), 2:573-576.

17. See Averroës In metaph. 7 text 31, fols. $180 \mathrm{vb}-181 \mathrm{vb} ; 12$ text 18 , fols. $393 \mathrm{rb}-$ 305rb; and Albert the Great Metaphysica 11.1.8, ed. Bernhard Geyer in Opera Omnia 16/2 (Münster: Aschendorff, 1964), pp. 468b-470a; Nicoletto Vernia, Quaestio an dentur universalia realia, in Urbanus Averroista philosophus summus. . . Commentorum omnium Averrois super librum Aristotelis De physico auditu expositor clarissimus (Venice, 1492), unnumbered folio 3rab. On Averroës's interpretation of Themistius here, see Charles Touati, "Les problèmes de la génération et le rôle de l'intellect agent chez Averroès," in Multiple Averroès, ed. Jean Jolivet (Paris: CNRS, 1978), pp. 157-164.

18. Nifo Expositio Destructio destructionum 9 doubt 2, fols. 97vb and 98ra. Albert is cited (fol. 98va) on the manner in which forms are contained in matter. On Vernia's and Nifo's acceptance of Albert's doctrine of inchoatio formae, see my articles, "Nicoletto Vernia's Question on Seminal Reasons," Franciscan Studies 38 (1978): 299-309, and "Philosophy and Science in Nicoletto Vernia and Agostino Nifo," in Scienza e filosofia all'Università di Padova nel quattrocento, ed. Antonino Poppi (Padua: LINT, 1983), pp. 135-202, at pp. 160-163 and 189-190. 
(in signifero seu orbe seminario). The souls then descend into bodies. When their descent (descensus) is completed, they are individual in their respective bodies. Subsequently, there will be the "great year" (annus magnus), that is, a great circuit, in which all things will return (redibunt) to the way they had been originally. This circuit or cycle will take place an infinite number of times and souls will often come back again (reiterabuntur). Nifo presumes that al-Ghazzali's problems regarding Plato's doctrine of the soul can be solved with this reading. The "root" (radix) to which souls return is not a single soul or Idea of a soul but rather the orb in which they abide and which Plato calls the "first nursery" (seminarium primum). ${ }^{19}$ What must be noted in particular is that the interpretation that Nifo has set forth here closely resembles the overall interpretation to be found in Albert the Great, an interpretation whose general outlines were also adopted by Nifo's teacher, Nicoletto Vernia. ${ }^{20}$

The lines that follow contain further remarks that may provide a key to Pico's interest in such an interpretation of Plato and also throw light on the general intellectual milieu of the period. Nifo relates that al-Ghazzali rejected the supposed doctrine of Plato that there is only one soul, since it would then follow that the soul of one human being is also the soul of another human, whereas in fact the soul of an individual human, say that of Peter, knows that it differs from another soul, say that of William. If all the souls of human beings were one, then their knowledge would also be one or identical, since

19. Nifo Expositio Destructio destructionum 1 doubt 8, fol. 9rb: "Sed licet haec opinio sit solennis ut vides, dixi sibi quod opinio Platonis non est ista, ut apparet in Phaedone. Et ei monstravi textum, cui non contradixit. Videbatur enim mihi Platonem velle animas esse creatas a deo in quodam numero certo et eas stare in signifero seu orbe seminario in gloria. Et tunc ponit quod illae descendunt ad corpora et cum completur eorum descensus sic quod singula in corpore fuerint, tunc erit annus magnus in quo iterum omnia ut prius redibunt. Et hoc fiet infinities, et reiterabuntur saepe. Et tunc vult ipse per radicem orbem signorum, quem appellat seminarium primum in quo stant. Et si ista est opinio Platonis, tam soluta est quaestio Algazelis."

20. See Albert the Great Summa de creaturis 2: De homine 5.2, ed. Borgnet, Opera Omnia 35 (Paris: Vivès, 1896), p. 67; and 5.3, 35:75 and 79-80. Compare Albert Liber de natura et origine animae 2.7-8, ed. Bernhard Geyer, Opera Omnia 12 (Münster: Aschendorff, 1955), pp. 30-32. On Vernia's interpretation of Plato's psychology, see Mahoney, "Nicoletto Vernia on the Soul and Immortality," in Philosophy and Humanism: Renaissance Essays in Honor of Paul Oskar Kristeller, ed. Mahoney (New York: Columbia University Press, 1976), pp. 144-163, at pp. 150-151. 
knowledge is an essential property of the soul. Nifo appears to consider al-Ghazzali's insistence that knowledge is a substantial property to rule out the possibility that souls were created in a set number and presumably would enter, depart, and reenter various human bodies over the course of time. ${ }^{21}$ But what is still more interesting is that Nifo also considers al-Ghazzali's subsequent remarks to touch on Averroës's doctrine of the unity of the intellect.

Al-Ghazzali himself-that is, the Latin al-Ghazzali as Nifo reads him-examines the proposal that there is but one soul which is divided according to its "dependence" (dependentia) on different bodies, but he rejects such a view on the ground that something lacking the magnitude of measurable quantity cannot be so divided. On the other hand, Nifo glosses the "dependence" in question as an "ordering" (ordo) to bodies. He notes, moreover, that the position seems to be that of the Peripatetics, since Averroës, himself a peripatetic (Averroes peripateticus), thinks that the intellect of all humans is numerically one in itself, though it can be multiplied extrinsically (extrinsece) according as it signifies an "ordering" to the different bodies of which it is the first perfection (perfectio prima). In a word, Nifo has placed al-Ghazzali's and Pico's supposedly similar readings of Plato's concept of the soul in the context of interpreting Averroës's doctrine of the unity of the intellect, a doctrine that Nifo believed at this point in his career to be the position of Aristotle himself. ${ }^{22}$ Indeed, Nifo even states that al-Ghazzali's arguments in the text under consideration preclude that one intellect (unus intellectus) could be many. ${ }^{23}$

21. Nifo Expositio Destructio destructionum 1 doubt 8, fol. 9rb. Nifo will return to this passage in his De intellectu.

22. On the shift in Nifo's evaluation of Averroës as an accurate interpreter of Aristotle, see Mahoney, "Agostino Nifo's Early View on Immortality," Journal of the History of Philosophy 8 (1970): 387-409.

23. Text of al-Ghazzali in Destructiones destructionum 1 doubt 8 , fol. 9ra, and Nifo, Expositio Destructio destructionum 1 doubt 8, fol. 9rb: "'Et si forte aliquis arguat, dicens quod sint unum animae,' id est, quod omnes animae sint unum, 'sed dividuntur secundum dependentiam,' id est ordinem ad corpus, sicut videtur opinio peripateticorum, vult enim Averroes peripateticus, ut dixi, quod intellectus omnium est unus numero in specie, potest tamen multiplicari extrinsice prout est dicens ordinem ad diversa corpora quorum est perfectio prima. Contra hoc arguit Algazel dicens: 'Nos dicimus quod dividi id quod magnitudinem quantitatis mensurabilium non habet est falsum.' Ergo supra impossibile est unicum intellectum esse multos respectu corporum." For the English translation of al-Ghazzali, see Averroes' Tahafut al-Tahafut, ed. Van Den Bergh 1:15. 
In his own rejoinder to these remarks of al-Ghazzali, Averroës takes up the possibility that Peter differs from William numerically but is one with him in form, namely, in their soul. In this case, if the soul does not cease at the cessation of the body, then, when it is separated from the body, it will of necessity be one in number. Although this might seem at first glance to be a concession to al-Ghazzali's interpretation of Plato, it is not. Averroës considers al-Ghazzali's argumentation against Plato to be sophistical. First of all, there is an equivocation at work regarding the terms "same" and "different," since they can have different meanings. The soul of William and the soul of Peter can be called "one" as regards their form and yet "many" as regards their substrata (ratione subiectorum) - that is, the different underlying "subjects" in which they exist, namely, human bodies. Furthermore, al-Ghazzali errs in saying that what lacks quantity cannot be divided, for it can be divided at least accidentally through its substrata. Indeed, Averroës insists that it is precisely in this way that form and soul are divisible, that is, by the division of their substrata (divisione subiectorum). He adds that the soul thus closely resembles light insofar as light is divided by the division of illuminating lights, whereas it again becomes one on the removal of these other illuminating lights. It is the same with the soul and bodies. ${ }^{24}$

In his commentary on this text, Nifo draws on his own understanding of Averroës's doctrine of the unity of the intellect. He explains that the "form of the human being" (forma hominis) — which is in fact the lowest of the Intelligences 25 - can be considered in two different ways, namely, as it is "soul" and as it is "intellect," that is,

24. Averroës Destructiones destructionum 1 doubt 8 , fol. 9va. In his translation from the Arabic text, Van Den Bergh reads "illuminated" and not "illuminating." See Averroës Tahafut al-Tahafut, ed. Van Den Bergh 1:16.11. This passage influenced Moses Narboni (c. 1300-1366) in a commentary that he wrote on one of Averroës's treatises on conjunction. Indeed, he appears to have fashioned a Plato "quotation" from Averroës's remarks. Moreover, he connects what he attributes to Plato with Averroës's doctrine of the unity of the intellect. See The Epistle on the Possibility of Conjunction with the Active Intellect by Ibn Rushd with the Commentary of Moses Narboni, ed. and trans. Kalman P. Bland, Moreshet Series, Studies in Jewish History, Literature, and Thought 7 (New York: Jewish Theological Seminary of America/KTAV, 1982), Introduction, p. 22. Bland (p. 113, n. 4) recognizes Averroës as Narboni's source and correctly excludes any genuine source in Plato or Plotinus.

25. On the lowest Intelligence as the forma hominis, see Nifo Expositio Destructio destructionum 1 doubt 8 , fol. $9 \mathrm{rb} ; 1$ doubt 23, fol. 23rb; and 6 doubt 2, fol. $74 \mathrm{vb}$. 
a separate substance. Going beyond the text-but in fact borrowing from Averroës's Physics and perhaps also from Walter Burley's commentary on that work ${ }^{26}$-Nifo argues that just as a column is "left" or "right" not of itself but from its "ordering" to different human beings (ex ordine ad diversos homines) standing near it in such fashion that there is no newness (novitas) or modification in the column, so too is the intellect "many souls" without any real multiplication occurring in it, for all multiplication comes about on the part of human bodies. Accordingly, the intellect can be called "many" per accidens and extrinsically - that is, without any modification in its very substance-just as the column is called "right" only per accidens by reason of the thing that is "right" simpliciter, that is, the objects near the column. The intellect can be considered "many" per accidens and extrinsically (extrinsece), that is, many "souls", as it regards (prout respicit) the bodies of different human beings. 27

Nifo thus considers Averroës to have reduced Plato to his own position insofar as he takes Plato to hold that the soul is in some way one and in some way many, since it is one simply and absolutely in its substance and yet many by its relationships to different substrata.

26. See Averroës In phys. 7 text 20; Aristotelis Opera 4, fol. 322va; and Walter Burley Expositio in libros octo De physico auditu 7 text 20, ed. Nicoletto Vernia (Venice, 1482), sig. K1va-K3ra.

27. Nifo Expositio destructio destructionum 1 doubt 8, fol. 9rb: "Debes scire quod forma hominis potest dupliciter considerari, videlicet inquantum anima et inquantum intellectus, substantia existens separata. Si primo modo, dico quod sicut columna est dextra et sinistra non per se sed ex ordine ad diversos homines sic quod nulla est novitas in ea sic intellectus prout respicit homines diversos est anima multa, non multiplicatione accidenta ei sed multiplicatione se tenente ex parte corporum. Et sic potest dici multus per accidens extrinsece sicut columna dicitur dextra per accidens ratione rei dextrae simpliciter. $\mathrm{Si}$ autem consideratur ut intellectus est, sic est unus per se et per accidens, quoniam ut sic separatur ab omni respectu ad quodcumque extrinsecum. Et sic anima est una quodammodo et plures quodammodo, una quidem per se et simpliciter, multae autem extrinsece et per accidens." A like interpretation of Averroes is given by Nicoletto Vernia, Nifo's teacher, in his Contra perversam Averrois opinionem de unitate intellectus et de animae felicitate quaestiones divinae (Venice 1505), fol. 6vb. This interpretation was vehemently attacked by the Franciscan theologian at Padua, Antonio Trombetta. See Mahoney, "Antonio Trombetta and Agostino Nifo on Averroes and Intelligible Species: A Philosophical Dispute at the University of Padua," in Storia e cultura al Santo, ed. Antonino Poppi (Vicenza: N. Pozza, 1976), pp. 289-301. 
Nifo himself attempts to aid Averroës's reading of Plato by suggesting that when Plato says man is nothing but his soul, insofar as he uses the body as its instrument, what is meant is that the soul remains one simply and absolutely like an individual artisan and yet becomes many in the way that the single artisan becomes many by using different instruments. Oddly enough, despite his having earlier challenged Pico's interpretation by citing the Phaedo and his having presented as Plato's position that God created a fixed number of individual souls, Nifo now states that the notion of a single soul for all does seem to be Plato's own opinion as he himself has written in his own De intellectu. ${ }^{28}$ This seeming discrepancy in Nifo's interpretation of Plato may be explained in various ways. Nifo may have offered the Phaedo passage and maintained that Plato held to a plurality of souls before he had read much Plato. Or again he might have simply been engaging in a dialectical joust with Pico and was not committing himself absolutely to the view that for Plato there was a fixed number of individual souls that had been created by God. In any case, throughout his career Nifo would continue to worry the question whether the soul was one or many for Plato. 29

Although Pico is mentioned again in Nifo's early commentary on the De anima, which was published in 1503, he is now cited not for his interpretation of Plato's psychology but for his views on whether we can believe a proposition to be true or false as we please. ${ }^{30}$ In this

28. Nifo Expositio Destructio destructionum 1 doubt 8, fol. 9rb: "Circa dicta primo debes scire quod opinionem Platonis Averroes reduxit ad opinionem eius intantum quod Plato ut Averroes innuit nihil aliud nisi sit quodammodo una et quodammodo plures. Est enim una simpliciter et absolute in substantia et plures respective et in habitudine ad diversa subiecta, ut dixi iam. Et hanc opinionem Averroes ascribit Platoni. Et addo quod Plato videtur dicere quod homo non est aliud nisi anima prout utitur corpore tanquam instrumento. Et ideo sicut navis est nauta tantum utens instrumento, sic homo est anima utens corpore tanquam instrumento et sicut artifex est quodammodo unus simpliciter et absolute, sic et anima. Et haec videtur opinio Platonis, ut scripsi in libro De intellectu."

29. For a more detailed discussion, see Mahoney, "Plato and Aristotle in the Thought of Agostino Nifo (ca. 1470-1538)," in Platonismo ed aristotelismo nel mezzogiomo d'Italia (secc. XIV-XVI), Biblioteca dell'Officina di Studi Medievali 1, ed. Giuseppe Roccaro (Palermo: Officina di Studi Medievali, 1989), pp. 79-102.

30. Agostino Nifo Collectanea ac commentaria in libros De anima (Venice, 1522) 2 coll. 153, fol. 146rb-va. I cite this edition for the sake of convenience. For the first edition, see Augustini Niphi super tres libros De anima (Venice, 1503). 
commentary, Nifo considers Averroës to be so true an interpreter of Aristotle that he calls him the "Arab Aristotle" (arabs Aristoteles). 31 Aristotle and Averroës are agreed on the doctrine of the unity of the intellect. ${ }^{32}$ On the other hand, Nifo shows strong interest in the possibility of conciliating Plato and Aristotle, and he explicitly mentions Ammonius, Themistius, and Simplicius along these lines. ${ }^{33}$ Nifo makes constant use both of Ermolao's translation of Themistius's paraphrases on the De anima and also of a now-lost translation of the De anima that has traditionally been attributed to Simplicius, and he prefers on occasion their explanations of the text to those of the Latins, namely, Albert the Great, Thomas Aquinas and Giles of Rome. ${ }^{34}$

Nifo reveals remarkable sensitivity to the Platonic orientation of the De anima attributed to Simplicius, listing Simplicius among other platonici like Plotinus and Origen and stating at one point that Simplicius's exposition seems to be more in accord with Plato than with Aristotle. ${ }^{35}$ Indeed he attempts to assimilate Themistius, Simplicius, and the Plotinus who emerges from Ficino's commentary on the Enneads, in a manner that bears on our topic of Pico's interpretation of Plato. Basing himself on Ermolao's translation of Themistius's paraphrases on the De anima, Nifo attributes to Themistius a theory of a rational soul which extends into each individual living body an "animation" (animatio) or "life" (vita), adding however that Themistius leaves in doubt whether this first soul, that is, the rational soul,

31. Nifo Collectanea 2 coll. 97, fol. 122vb.

32. Nifo Collectanea 1 coll. 12, fol. 20rb-21va; compare 3 coll. 1 , fol. 2ra-b; 3 coll. 5 , fol. $11 \mathrm{rb}-\mathrm{va}$.

33. Nifo Collectanea 1 coll. 36, fol. 65va. For Nifo's "conciliation" of Plato and Aristotle on divine knowledge and on whether unity is above being and the other transcendentals, see 2 coll. 5, fol. 16rb-va. Garin thinks that on the latter question Nifo has rejected Pico for Ficino. See Eugenio Garin, La cultura filosofica del Rinascimento italiano (Florence: Sansoni, 1961), p. 117.

34. In Collectanea 3 coll. 5 (fol. 16vb), Nifo also cites Simplicius's De coelo and Physics. In the commentary on the Destructio, Nifo cited both these works but not the De anima that is attributed to Simplicius. His use of this latter work in his own early commentary on the De anima has been noted by Nardi, Saggi, pp. 377-382. The Greek Commentators would come to have an ever greater importance in Nifo's philosophical works.

35. Nifo Collectanea 3 coll. 23-24, fols. 47va and 48rb. 
is one or many-in the later De intellectu he will take Themistius to hold it to be one. What is significant for our purposes here is that Nifo takes Themistius to attribute this same theory to Plato and Aristotle, and he himself goes on to see it present in Plotinus's Enneads 1.36 This explication of Themistius is clearly inspired by remarks of Marsilio Ficino who, in his own commentary on the Enneads, takes the rational soul, the "first soul," to pour forth into the body a "life" (vita), which is properly called an "animation" (animatio) and "vivification" (vivificatio), whereas the rational soul alone is properly called "soul." Ficino appears to believe that Themistius adopted from Plato and Plotinus a conception of a single intellect informing the many rational souls which he then attributed to Aristotle. ${ }^{37}$ Moreover, Nifo uses almost the same passages from Ficino to explicate the psychology that emerges from the commentary on the De anima attributed to Simplicius. ${ }^{38} \mathrm{He}$ even cites Themistius's supposed notion of "animation" when explicating how one intellect provides the soul

36. Nifo Collectanea 2 coll. 37, fols. 93vb-94ra. For the source in Themistius, see Themistius In libros Aristotelis De anima paraphrasis, ed. R. Heinze, Commentaria in Aristotelem Graeca 5/2 (Berlin: G. Reimer, 1899), pp. 25-27. Compare Themistius Libri paraphraseos . . . in libros De anima 1.23, in Libri paraphraseos Themistii in Posteriora Aristotelis, in Physica, in libros De anima. . . interprete Hermolao Barbaro (Treviso, 1481), sig. bb2r-bb2v. See Plotinus Enneads 1.1.7, 1.1.10, and 1.1.12.

37. Marsilio Ficino, argumenta to Enneads 1.1.1 and 1.1.7, in Opera Omnia (Basel, 1576), pp. 1548-1549 and 1551-1552. For a presentation of the relevant passages in Themistius's paraphrases on the De anima and their impact on earlier medieval philosophers, see Mahoney, "Themistius and the Agent Intellect in James of Viterbo and Other Thirteenth-Century Philosophers (Saint Thomas, Siger of Brabant, and Henry Bate)," Augustiniana 23 (1973): 422-467, especially pp. 424-431. See also Mahoney, "Neoplatonism, the Greek Commentators, and Renaissance Aristotelianism," in Neoplatonism and Christian Thought, ed. Dominic J. O'Meara (Albany: SUNY Press, 1982), pp. 169-177 and 264-282, especially pp. 171-172 and 264-266. There are detailed surveys of the scholarly literature in the notes of these two studies.

38. Nifo In De anima 3 coll. 1, fol. 1rb. Compare Nardi, Saggi, pp. 378-379, who identifies some of the passages that Nifo quotes from Simplicius, but who does not notice Nifo's clear dependence on Ficino. For a more general discussion, see Mahoney, "Marsilio Ficino's Influence on Nicoletto Vernia, Agostino Nifo, and Marcantonio Zimara," in Marsilio Ficino e il ritorno di Platone: Studi e documenti, ed. Gian Carlo Garfagnini (Florence: Olschki, 1986), 2:509-531, at pp. 517-524. Eckhard Kessler does not bring out Ficino's influence on Aristotelians of the Renaissance in his study, "The Intellective Soul," in The Cambridge History of Renaissance Philosophy, ed. Charles B. Schmitt, Quentin Skinner, and Eckhard Kessler (Cambridge: Cambridge 
for many individual human beings. ${ }^{39}$ Whether or not Nifo has interpreted Themistius and Simplicius in a wholly accurate fashion, he has correctly seen that the problem of the one and the many was central for them and related to a like worry in Plotinus. 40

The De intellectu is of course Nifo's major early work touching on questions of philosophical psychology. It is also one of the works in which he shows strong interest in delineating the similarities as well as the differences among various philosophers of antiquity and the medieval period. He appears to be the first Aristotelian commentator of the Renaissance to compare in detail the platonici, especially Plotinus, both with Themistius and Simplicius and also with Averroës. This interest in Simplicius and Themistius he shared with his own teacher, Nicoletto Vernia, as well as with Pico himself. ${ }^{41}$ But it must be added

University Press, 1988), pp. 484-534. Some of his remarks on Vernia, Nifo, and Pomponazzi are imprecise.

39. Nifo De anima 3 coll. 20, fol. 44rb. Nifo's reading of Simplicius is not wholly accurate here.

40. It should be noted that in De anima 3 coll. 5 (fol. 10va), Nifo does seem to believe that the intellect is one in number for Themistius. For further discussion on Nifo's relating Plotinus to the two Greek Commentators, see Mahoney, "Neoplatonism, the Greek Commentators, and Renaissance Aristotelianism," pp. 171-173 and 272-274. What gives Nifo's approach to Simplicius an unusual twist is that he takes Simplicius to have held that the single intellect together with the individual "life" in each human being forms the "whole soul" (tota anima) or the "whole rational soul" (tota anima rationalis), that is, a certain essential unity (quoddam unum essentiale). Nifo has thus applied to Simplicius a terminology that he took from an interpretation of Averroës found in Siger of Brabant's now lost De intellectu. Although Nifo accepted Siger's explication of Averroës as correct when he wrote his early commentary on the De anima, he would abandon it soon thereafter in the De intellectu and attack Pico for having adopted it. On Siger's theory, see Bruno Nardi, Sigieri di Brabante nel pensiero del Rinascimento italiano (Rome: Edizione Italiane, 1944); and Mahoney, "Saint Thomas and Siger of Brabant Revisited," Review of Metaphysics 27 (1974): 531-553; and Mahoney, "Sense, Intellect, and Imagination in Albert, Thomas, and Siger," in The Cambridge History of Later Medieval Philosophy, ed. Norman Kretzmann, Anthony Kenny, and Jan Pinborg (Cambridge: Cambridge University Press, 1982), pp. 602-622.

41. On Pico's interest in Simplicius and Themistius, see Nardi, Saggi, pp. 373375; Garin, Storia della filosofia italiana, pp. 460-462; and Kristeller, "Giovanni Pico della Mirandola and His Sources," pp. 54-55 and 62. There are conclusiones for Themistius and Simplicius in Pico's Conclusiones, ed. B. Kieszkowski, pp. 39-41. In an earlier study, Kieszkowski had argued that Pico's entire knowledge of Themistius and Alexander was based on questions and commentaries prepared for him by Elia del Medigo. Supposedly only after Pico had composed the Conclusiones did he study the 
that the remarks made about the platonici and even about Plato are at times inspired by statements to be found in the writings of Albert the Great. ${ }^{42}$ We might thus characterize Nifo as under the joint influence of Renaissance Platonism (through the works, the translations, and the commentaries of Ficino) and of medieval Platonism (through the writings of Albert). As we shall see, Pico, too, borrows from a work of Albert in his approach to Plato's psychology. 43

On occasion in the De intellectu, Nifo appears to attribute to Plato himself belief in personal immortality. ${ }^{44}$ And while platonici like Plotinus and Iamblichus are presented, on the one hand, as holding that in

Greek Commentators directly. See Bohdan Kieszkowski, "Les rapports entre Elie del Médigo et Pic de la Mirandole (d'après le ms. lat. 6508 de la Bibliothèque Nationale)," Rinascimento 4 (1964): 41-91, at p. 53. The author's remarks on Pico, Themistius, and Simplicius are questionable. For recent valuable discussions on Elia, see Herbert Davidson, "Medieval Jewish Philosophy in the Sixteenth Century," in Jewish Thought in the Sixteenth Century, ed. B. D. Cooperman (Cambridge: Cambridge University Press, 1983), pp. 106-145, at pp. 110-111; and Alfred L. Ivry, "Remnants of Jewish Averroism in the Renaissance," in the same volume, pp. 243-265, at pp. 250-261. Of special relevance here is Kalman P. Bland's important new study, "Elijah del Medigo's Averroist Response to the Kabbalahs of Fifteenth-Century Jewry and Pico della Mirandola," Journal of Jewish Thought and Philosophy 1 (1991): 23-53.

42. The mixture is strikingly apparent in Nifo Liber de intellectu 1.1.8 (Venice, 1503), fol. 5va, where he presents "Platonic arguments" (demonstrationes platonicae) from Plotinus that are borrowed to the word from Ficino's argumentum to Enneads 4.7.epilogue, in Opera Omnia, 1754. His "other argument of Plato" (alia Platonis ratio) and the argument cited from the Phaedrus (De intellectu 1.1.8, fol. 6rab) are taken from Albert De natura et origine animae 2.1 (12:18-19), and 2.6 (12:26-27). For discussion, see my "Agostino Nifo's Early Views," pp. 451 and 456-457.

43. On Nifo's "Albertism," see my "Albert the Great and the Studio Patavino," pp. 551-554. Because he does combine what he learns about Plato's teachings both from reading Plato himself in Ficino's newly available translations and also from reading what Albert and Ficino attribute to Plato and the platonici, Nifo would come to express in his later writings his own puzzlement as to Plato's position. It is no surprise then that in his De immortalitate animae and his second, Pisan commentary on the De anima he should take up Eusebius's charge that Plato was inconsistent in his remarks about the soul. For details and discussion, see Mahoney, "Plato and Aristotle in the Thought of Agostino Nifo," pp. 91-96. For a major contribution to our knowledge of Plato's impact on the Renaissance, see James Hankins, Plato in the Italian Renaissance, Columbia Studies in the Classical Tradition 17 (Leiden: E. J. Brill, 1990).

44. Nifo De intellectu 1.1.9, fol. 6va. See Opera Platonis, trans. Marsilio Ficino (Venice, 1491), fol. 262vb, for the Timaeus passage; fol. 180rb-va, for the Phaedo passage. 
the preexistent state there are many distinct rational souls, Theophrastus, Themistius, and Averroës are presented, on the other hand, as holding that the rational soul is a single Intelligence. ${ }^{45}$ When Nifo does turn to Themistius and Theophrastus in particular, he explains that they hold that there is one soul for all living things, called the world-soul (mundi anima), that sends forth an "animation" (animatio), "life" (vita), or "soul" (anima) into all living things, just as the sun sends forth illuminations into all bright things. This same world-soul is also called "the intellect of the human being" (intellectus hominis) insofar as it sends forth the power of thinking to the soul. What is important for our purposes is that Nifo quotes passages from Ficino's translation of Timaeus 34B and 41C which appear to show that Plato, too, held to a world-soul that universally vivifies all living things by extending to them an animation (animatio) or life (vita) and that is like a seed (semen) and principle (principium) containing within its own power (continens in sua virtute) all the forms and all the activities of all the forms. He adds that Themistius himself takes Aristotle to be speaking of such an animation or "second soul" (anima secunda) and not the soul which is one for all-when he calls the soul the first act. According to Nifo's reading of Themistius, there is, then, no conflict between Plato and Aristotle on the distinction between the one single rational soul and the individual "animation" (animatio) or "second soul" (anima secunda) that is found in the individual living thing. ${ }^{46}$ On several occasions in the De intellectu, Nifo returns to this theory of the world-soul that he has attributed to Themistius and that

45. Nifo De intellectu 1.1.17, fols. 9vb-10ra.

46. Nifo De intellectu 1.1.17, fol. 10rb-va. Nifo is closely following here Ermolao's translation. See Themistius Libri paraphraseos . . . in libros De anima . . . interprete Hermolao Barbaro 1.23, sig. bb2r-v, cited above in note 32 . Nifo returns to Themistius's interpretation of Plato as upholding a single soul and also individual souls in 1.2.18, fol. 24rb, where he quotes from Ermolao's translation about Plato in Libri paraphraseos . . . in libros De anima 3.38, sig. ff4r-v. Compare Themistius In libros Aristotelis De anima paraphrasis, ed. R. Heinze, p. 107, lines 23-29. Nifo challenges Themistius's conciliation of Plato, Aristotle, and Theophrastus. See Nifo De intellectu 1.5.21, fol. 52rb-va. In doing so, he may also intend to criticize Vernia. On the latter's conciliation of Plato and Aristotle, see Mahoney, "Nicoletto Vernia on the Soul and Immortality," pp. 153, 155, and 158-162; "Neoplatonism, the Greek Commentators, and Renaissance Aristotelianism," pp. 170-171 and 268-269; and "Philosophy and Science in Nicoletto Vernia and Agostino Nifo," pp. 167-168 and 171-172. 
he had already discussed in his earlier commentaries on the Destructio destructionum and the De anima. 47

In one discussion regarding Themistius and the platonici, Nifo begins by noting that "outstanding men of Plato's sect" (praestantissimi viri ex Platonis secta) hold that the rational souls (rationales animae) flow from the world-soul (anima mundi) and that these souls give human beings their existence and put them in their species. Some of the followers of Plato say that the rational souls are parts of the world-soul, a position that Plato sometimes appears to maintain. Nifo cites the Philebus, Phaedrus, Timaeus, and the Republic to justify this statement about Plato. However, he is careful to distinguish Plato from those who identify the world-soul with God, noting that Plato would perhaps say, as is obvious from the Timaeus, that God and the world-soul differ and that the world-soul is located in the middle of the world. 48

Nifo then turns from the platonici to later philosophers (posteriores philosophantes), such as Themistius, Theophrastus, al-Ghazzali, and Avicenna, who thought that all the souls of living things flowed from the world-soul just as illuminations (illuminationes) flow from the sun. They do not hold that the numerically one rational soul, called "the world-soul" (anima mundi), directly animates within living things (intus viva) but that it provides all living things with individual souls that are also called rational souls. Nifo explains how it is necessary according to Themistius to postulate two such rational souls (duae rationales animae). The one rational soul is individual, inseparable from the body, and destructible at the death of the body. This is the

47. Nifo De intellectu 1.1.24, fol. 13rb. Nifo again cites what he takes to be Themistius's account of the phenomenon of spontaneous generation. See Themistius Libri paraphraseos . . . in libros De anima 1.23, sig. bb2r-v. Compare Themistius, In libros Aristotelis De anima paraphrasis (Heinze 25-26). For other relevant passages in Nifo De intellectu, see 1.1.7 (fol. 19ra1), 1.1.18 (24rb), 1.3.9 (31 ra), 1.3.20 (33rb34ra), 1.4.14 (41va), 1.5.10 (48va-b), 1.5.11 (49ra), 1.5.13 (49vb), and 1.5.22 (52vb). For the colcodea language, see 1.4 .9 (40ra) and 1.4.11 (40va), as well as Nifo De demonibus 2.15, in De intellectu, fol. 80rb. On Nifo's adoption of this terminology for Avicenna's dator formarum, see Harry A. Wolfson, Studies in the History of Philosophy and Religion, 2:574-576.

48. Nifo De intellectu 1.1.24, fol. 13ra-b. The citations presented in behalf of the view that God is the world-soul are borrowed from Albert the Great De homine 5.2 (Borgnet 35:68a and 71a). 
soul that Themistius calls "the rational soul" and that Aristotle says he is defining in book 2 of the De anima. The other rational soul is separate and one in number for all living things and all animals. This is the soul that Themistius calls both "the intellect of the human being" (intellectus hominis), since it provides the power of thinking, and also "the world-soul" (mundi anima). Avicenna, on the other hand, calls it the "giver of forms" (dator formarum), while Averroës calls it an Intelligence (intelligentia). However, Nifo appears puzzled as to the precise nature of the individual rational soul or "animation" for Themistius and seems to suggest several lines later that it was a "creation" for the ancient commentator. Nifo contrasts those who speak of "animations" (animationes), "lives" (vitae), or "second lives" (animae secundae) coming forth from the world-soul-presumably the "outstanding men of Plato's sect" mentioned earlier-with Themistius and others of his sect (alii suae sectae) who say that the animation comes from the world-soul as a creation (creatio). 49

To make clearer the nature of the animations that flow from the world-soul according to these platonici, Nifo turns to the very same comparison that Pico had used to represent his own account of how there was for Plato one Idea of souls and yet many souls. Nifo first explains that for these platonici the animation comes forth from the world-soul neither by "creation" (creatio), as with Themistius and his followers, nor by the division of the world-soul, but rather through an "impression" (impressio) left by the world-soul from its entering (ingressus) into the body. He then offers an example of such a process that he says is given by John Saracene (Joannes Saracenus), and he expressly points out that this example or comparison is narrated by Albert the Great. Just as in vaults and arches of walls (in testudinibus ac parietum arcubus) a wooden arch is first set up on which the vault is completed, and after that arch has been removed there remains both its "trace" (vestigium) in the vault and also the separate arch (separatus arcus) itself, so too the world-soul (anima mundi) animates living substances by means of a "trace" (vestigium) in that living substance. ${ }^{50}$

49. Nifo De intellectu 1.1.24, fol. 13rb-va. Nifo's interpretation of Themistius on "animation" owes much to Averroës. For the latter's presentation of Themistius on generation, see Touati, "Les problèmes de la génération."

50. Nifo De intellectu 1.1.24, fol. 13vb: "Post hos adhuc animationes ac vitas, quae animae secundae nuncupantur, dicunt $a b$ anima mundi provenire, non quidem per creationem ut Themistius et alii suae sectae, nec per divisionem animae mundi, 
In a word, Nifo appears to have discovered in Albert the source of the analogy that Pico had related to him during their journey together to Ferrara some years earlier.

It should be carefully noted that Nifo has somewhat bent the passage from Albert to his own purposes. Although the passage does concern Plato's remarks in Timaeus 41 A-D, the supposed quote from John Saracene that is found in Albert refers not to the worldsoul (anima mundi) but rather to "Idea-Forms" (formae ideales) which inform sensible substances. ${ }^{51}$ In the same chapter, Albert himself appears to take Plato to be saying that all forms are induced in matter by a giver of forms (dator formarum) that is an Idea (idea) separated from matter. The form induced in matter is called an "image" (imago), since it imitates the forming form that is outside matter. Albert points out that some people have called such an image a "reverberation" (resultatio), while others have called it a "shadow" (umbra) inasmuch as it darkens on entering matter. ${ }^{52}$ And elsewhere in his Metaphysics Albert refers to such an image as a "life" (vita). ${ }^{53}$ It would thus appear that Pico borrowed not only the comparison of the arch from Albert but also his interpretation of Plato according to which there is a single Idea which leaves its "reverberation" (resultatio) or "trace" (vestigium) in individual human beings. Indeed, the interpretation of Plato that Pico offers seems closer, as we shall now see, to that of Albert than does that of Nifo.

Whatever be the accuracy of Nifo's presentation of this passage from Albert regarding Plato, it is striking that Nifo himself makes

sed per impressionem relictam ex ingressu eius in corpus. Cuius exemplum Joannes Sarracenus dedit Alberto narrente dicens quod quemadmodum in testudinibus ac parietum arcubus primo ligneus supponitur arcus super quem testudo concluditur et postea remoto arcu remanet vestigium in testudine ac separatus arcus remanet, ita est in mundi anima animante substantias vivas, quae non nisi per vestigium est in viva substantia. Et hoc iuramentum erat deorum, quod Appollo reddit sacramento."

51. See Albert Metaphysica 11.1.8 (16:469.13-24).

52. Albert Metaphysica 11.1.8 (16:468.68-85 and 470.31-32/68-76). Albert himself rejects this view of Plato that forms are not educed from (educitur), but are rather induced (inducitur) in, the potency of matter (16:471.5-7). See also Albert Metaphysica 1.4.9 (16:60.33-36). It has been suggested that Albert here has borrowed his interpretation of Plato from Boethius. See Georg Wieland, Untersuchungen zum Seinsbegriff im Metaphysikkommentar Alberts des Grossen, BGPTM NS 7 (Münster: Aschendorff, 1972), p. 73, n. 33.

53. Albert Metaphysica 1.1.2 (16:4.20). 
heavy use of Albert to claim that the position he has ascribed to Plato was maintained by various platonici. $54 \mathrm{~A}$ few chapters later, when presenting the "true position" on the origin of the soul, which is borrowed word for word from Albert's De natura et origine animae, Nifo himself turns to Timaeus 41CD. While Albert had used this passage just after ascribing to Plato the view that there are Ideal Forms in the divine mind, Nifo reads it to mean that Plato understood by the seed (semen) a light from which all things flow and which Plato took to be the soul situated in the middle of things, vivifying them all. Nifo adds that if Plato did think this then his view can be reduced to what Nifo is defending-and borrowing from Albert-namely, that God produced all things from God's own light. ${ }^{55}$ However, it should not be thought that Nifo eliminates the notion of Divine Ideas or exemplars from his own presentation of Plato. When he takes up the question whether there can be more than one world, he suggests that Plato allowed this possibility insofar as he says in the Timaeus that the sensible world is made in accord with the exemplar (exemplar) of the intelligible world (mundus intelligiblis), that is, the Idea of the world (idea mundi). And just as there can be many houses of the same nature and yet only one Idea of a house, so there could be many worlds (plures mundi) from God's one sole Idea (una dei sola idea). ${ }^{56}$

When Nifo returns yet again to contrast Themistius and Theophrastus to the platonici, he draws both on Albert's De natura et origine animae and also on Ficino's commentary on his translation of the Enneads of Plotinus. What is both striking and of special importance here is that Nifo now uses a comparison very similar to that of the wooden arch and the impression it leaves in the resulting stone arch when it is removed. The comparison that he offers is of the impression left in wax when a ring that has been pressed against it is removed. This comparison, too, is drawn from one of Albert's discussions regarding Plato. Following Albert closely, Nifo points out

54. Nifo De intellectu 1.1.24, fol. 13va. See Albert De homine 5.3 (Borgnet 35:79b), 27.3 (152ab), 21.1 (176a), 61.2 (523b). For Isaac, see also Albert De anima 2.1.8, ed. C. Stroick, Opera Omnia 7 (Münster: Aschendorff, 1968), p. 76ab.

55. Nifo De intellectu 1.1.28, fols. 15vb-16ra. See Albert Metaphysica 1.5 .12 (16:64), and 1.5.15 (16:89). Albert combines the notions of the Divine Ideas, "seed," and light in his own discussion of Plato.

56. Nifo De intellectu 1.3.5, fol. 30ra. Pico and Henry of Ghent are mentioned later in the chapter. 
that Plato distinguished two kinds of form. The first kind is that of forms ante rem, that is, an exemplar and model (exemplar et paradigma) existing universally, immaterially, and simply in the intellect moving in nature, that is, God. These forms are called "first forms" (formae primae) because they have the power of forming things. ${ }^{57}$ The second kind of form is that which the platonici call "images" (imagines) of the first sort of form. They are as it were like the "imprint" in wax from a ring (sigillum ab annulo in cera), since the forms in matter, as Plato says, come from separate intelligible forms (separata intelligibilia formalia) as if from a certain "imprint" (ethermagrum). 58 Oddly enough, Nifo now borrows this comparison from Albert in order to explicate the doctrine of the world-soul that he had ascribed to Themistius, despite the fact that he had earlier contrasted Themistius with the platoniciThemistius supposedly held that the animation was "created" by the world-soul, whereas the platonici held that it was an "impression" from the world-soul. Needless to say, the present-day reader may justifiably question whether the same sort of comparison can helpfully illuminate different conceptions of the vivifying process. It is possible, of course, that Nifo's dependence on this comparison reveals his own puzzlement as to what Themistius actually meant by the "creation" of an animation-if we concede to Nifo his interpretation of Themistius.

Nifo recounts that according to Plato the mind of the First Intellect is the form ante rem containing in itself all possible images (imagines); this form can be likened to the figure of a ring which contains all living things. The similarity between Plato and Themistius that Nifo goes on to delineate is that the many "souls" that Themistius sees flowing from the one world- soul and which different people variously call "lives" (vitae), "animations" (animationes), "reverberations" (resultationes), "images" (imagines), "traces" (vestigia), and "impressions" (impressiones) are comparable to the figures or shapes left in wax by a ring. Nifo discerns a resemblance between the view of the soul that he attributes to Themistius and Theophrastus and the view of such

57. See also Albert Metaphysica 1.4 .9 (16:60).

58. Nifo De intellectu 1.2.7, fols. 18vb-19ra. See Albert De natura et origine animae 1.2 (12:4-5), and Ficino, argumentum to Enneads 1.1.7-8 (pp. 1551-1552). The comparison to a figure or image impressed in wax also appears in Albert's Metaphysica at 1.4.13 (16:66.73-75), and at 11.1.8 (16:471.3-4), and in his De intellectu et intelligibili 1.2.5 (Borgnet Opera Omnia 9 [Paris: Vivès, 1890], p. 496). The term ekmageion occurs in the Timaeus 50C. 
platonici as Porphry, Iamblicus and Plotinus. None of them thinks that the one and single soul directly animates living things; their position is rather that its animating power (virtus animativa) extends a "life" into the living thing. In Nifo's judgment, Themistius and these platonici thus stand opposed to Aristotle's conception of the soul.59

By this point it should be abundantly clear that Pico's account of Plato's theory of the soul as narrated by Nifo was indebted to Albert the Great, especially to the passage in his Metaphysics containing the comparison from "John Saracene." Oddly enough, this connection between Pico and Albert has not been noted by scholars interested in Pico. What has been detected by Bruno Nardi and others is a supposed connection between Pico and both Simplicius and Siger of Brabant: it is Nifo himself who provides the most significant clues relating Pico to these two philosophers. A detailed examination of Nifo and Pico, on the one hand, and Simplicius and Siger, on the other, would take us beyond the bounds of the present study, but surely enough should be set forth to bring out the connection of Pico's views on Siger to his views on Plato that we have just now examined.

Nifo sets forth as the true interpretation of Simplicius's account of the unity and the multiplicity of rational souls that from the single intellect that is one for all humans, on the one hand, and the sensitive or cogitative souls, on the other hand, there results a certain whole (quoddam totum), namely, the "rational soul," which is individual with each human being and numbered according to the number of existing bodies. This rather distorted reading of Simplicius enables Nifo to claim that for that commentator the intellect is one and yet the

59. Nifo De intellectu 1.2.8, fol. 19rb. On the other hand, Nifo pits the platonici and Themistius against one another in 1.3.12-13, fol. 31 rb-vb, on the grounds that the former, especially Plotinus, hold there to be a plurality of intellects that are immortal by reason of a plurality of rational souls or "first lives" which extend "second lives" into individual human bodies. Basing himself on texts from Averroës and from Ermolao's translation of Themistius, he takes Themistius to have been unable to explain how there could be rational souls which were both separate from matter and also numerically many. See especially Themistius Libri paraphraseos . . . in libros De anima 3.32-33, sig. ff2v-ff3r, and In De anima paraphrasis (Heinze 103.20104.23). Themistius is identified with Averroës and Theophrastus as holding an erroneous position (error purus) on the unity of the intellect in De intellectu 1.3.30, fol. 37va. At 1.5.21 (52rb-va), Nifo also rejects Themistius's attempt to reconcile Plato and Aristotle. 
multiplicity of rational souls, each of which gives existence to an individual human, can be saved. Adding that many believe this to be the mind of Plato himself, Nifo quotes from al-Ghazzali's statement in the Destructio that the opinion of Plato is that the one and eternal (una et antiqua) soul is divided according to the division of bodies but returns (redit) to its source (radix) when it is separated from the body. He then quotes Averroës's comment on this text from al-Ghazzali, namely, that the soul of Peter and the soul of William can in some way be said to be one and the same (una et eadem) on the part of the form but in another way be many by reason of their substrata (ratione subiectorum ). He also quotes Averroës's later remark in the Destructio that all the wise commonly think that the newness (innovatio) of the soul is wholly relative, since it results from its ability to be joined to different bodies, as well as Averroës's remark in his long commentary on the Metaphysics that for Aristotle the form of humans as they are humans results from their union (continuatio) with the intellect. Nifo then notes that some take from these passages that Averroës, like Simplicius, holds the intellect to be one for all human beings though it is multiplied and numbered in human beings as their individual "rational soul" (rationalis anima). ${ }^{60}$ Since these passages that Nifo has quoted from al-Ghazzali's Destructio and Averroës's own Destructio are the very ones that occasioned his discussion of Pico in his commentary on those works, it seems safe to infer that Pico himself presented the reconciliation of Simplicius and Averroës that Nifo has presented here. Nonetheless, it is instructive to note that in the very next chapter of the De intellectu, Nifo presents texts and arguments from Averroës to show the falsity of such an interpretation of the latter's psychology. ${ }^{61}$

Pursuing his ideal of exhaustive coverage of all possible positions, Nifo next sets out Siger of Brabant's attempt to mediate between Averroës and medieval Latins so as to assert the unity of the intellect with Averroës and yet assert that the intellect constitutes each human being in his or her individual existence as this individual human

60. Nifo De intellectu 1.3.16, fol. 32ra-b. See the texî of al-Ghazzali in Destructiones destructionum for 1 doubt 8 (fol. 9ra), quoted above in note 11. See also Averroës Destructiones destructionum 1 doubt 8 (fol. 9va) and doubt 23 (23ra), as well as Averroës In metaph. 12 text 38, fol. $321 \mathrm{rb}$.

61. Nifo De intellectu 1.3.17, fol. 32rb-va. Nifo would later reverse his position in the Pisan commentary on the De anima. 
being. ${ }^{62}$ Nifo now reveals that Giovanni Pico (Joannes Picus), in order to show that he could sustain any position howsoever false, attempted in discussion with Nifo to justify this position as being in accord with Aristotle, Averroës, Themistius, and all the ancient commentators on Aristotle-presumably Simplicius would be one of the latter. Evidently Nifo and Pico had engaged in debate regarding Siger's thesis, for while marshaling some twenty-seven passages and arguments culled from Averroës himself against that thesis, Nifo notes Pico's attempts to blunt the force of two of these passages. 63

Having demonstrated that Siger's position does not square with the mind of Averroës himself, Nifo now sets out to show that the others whom Pico had claimed could be reconciled with Siger's view actually held opposed positions. Turning to Themistius, he cites passages from Ermolao's translation of the paraphrases on the De anima in order to show that for the ancient commentator the "whole rational soul" (tota rationalis anima) is composed only of the agent intellect and the potential intellect. 64 Furthermore, Averroës sees the single rational soul united to individual humans operationally through the cogitative power whereas Themistius sees the one rational soul united to humans by the animation that it extends to each individual human being. 65 Nifo also denies that Themistius and Simplicius agree on the nature of the soul and intellect. 66

Nonetheless, Nifo does go on to suggest that Averroës, Themistius, and all philosophers-Plato included-take as a self-evident proposition that there can be a multiplicity of individuals within the same species only through the division of matter. Basing himself on remarks

62. Nifo De intellectu 1.3.18, fols. 32vb-33ra. Nifo relates Siger's position as found in the latter's now lost De intellectu, which was written in reply to Aquinas's De unitate intellectus contra Averroistas. For discussion, see Nardi, Sigieri di Brabante, pp. 11-38; Mahoney, "Saint Thomas and Siger of Brabant Revisited," pp. 537-540; Mahoney, "Sense, Intellect, and Imagination in Albert, Thomas, and Siger," pp. 613-616; Fernand Van Steenberghen, Maître Siger de Brabant, PM 21 (Louvain: Publications universitaires, 1977), pp. 360-363. See note 41, above.

63. Nifo De intellectu 1.3.19, fol. 33ra-vb. Garin reproduces key excerpts from this chapter in his edition of Pico, De hominis dignitate, pp. 85-86. See the first and seventeenth arguments of Nifo for Pico's counterinterpretations.

64. Nifo De intellectu 1.3.20, fol. 34ra.

65. Nifo De intellectu 1.3.23, fol. 34va. See also 1.3.20, fols. 33vb-34ra.

66. Nifo De intellectu 1.3.22, fol. 34rb. 
of Aristotle and Thomas Aquinas, Nifo argues that Plato did not hold a multiplicity of Ideas that were similar in species, since the very cause of their being individuals, namely, matter, was lacking. ${ }^{67}$ Nifo thus appears to see a parallel between Averroës's postulating only one intellect for all human beings (since it is separated from matter and therefore from whatever would cause it to be multiple) and Plato's postulating an Idea of the human being that is by essence (per essentiam) numerically one (because he holds that by its very essence that Idea is separated from individuals and exists without matter). Nifo again appeals to Siger's De intellectu for an account of how the intellect can be one for Averroës and yet be the form of the many human beings who actually exist. Noteworthy for the development of the "Albert connection" is that Nifo here presents Siger as a serious man who belonged to the Averroist sect during the time of the "Expositor," that is, Thomas Aquinas, and who was a disciple of Albert the Great (Suggerius vir gravis, sectae Averroisticae fautor aetate expositoris, discipulus Alberti). 68

What surely merits attention is that in this same chapter Nifo has seen a parallel between Averroës's one intellect for all human beings and Plato's single Idea for all human beings, based on their acceptance of matter as the principle of individuation, and has again recounted from Siger's De intellectu a way to reconcile Averroës's doctrine of the unity of the intellect with the plurality of humans-a solution that Nifo had told us Pico himself had adopted. But even more significant

67. Nifo De intellectu 1.3.24, fol. 34vb. See Themistius Libri paraphraseos. . . in libros De anima 3.32, sig. ff2v; compare his In De anima paraphrasis (Heinze 103.2630). The relevant passage in Aristotle is Metaphysics 1.6.987b14-18. Nifo quotes from Thomas Aquinas Super Metaphysicam 1.10, ed. M. R. Cathala and R. M. Spiazzi (Turin: Marietti, 1971), no. 157. He follows Thomas's use of the concept of matter as the principle of individuation in order to analyze Plato's theory of ideas. See Thomas Super Metaphysicam 1.10, nos. 154-155, but also 1.14, no. 209. On the problem of individuation in medieval philosophy, see Johannes Assenmacher, Die Geschichte der Individuationsprinzips in der Scholastik (Leipzig: F. Meiner, 1926); Jorge J. E. Gracia, Introduction to the Problem of Individuation in the Early Middle Ages (Munich: Philosophia, 1984); and Joseph Owens, "Thomas Aquinas: Dimensive Quantity as Individuating Principle," Mediaeval Studies 50 (1988): 279-310.

68. Nifo De intellectu 1.3.26, fol. 35va-b. On the problem of the connection between Siger and Albert, see Albert Zimmermann, "Albertus Magnus und der lateinische Averroismus," in Albertus Magnus: Doctor Universalis 1280/1980, ed. G. Meyer and A. Zimmermann (Mainz: Matthias Grünewald, 1980), pp. 465-493. 
is that when Nifo attempts to explain how in fact the intellect is one for Averroës and yet can be called many souls, he refers the reader to the very passages in the Destructio that were the occasion for his narrating Pico's account of how Plato could maintain there is only one soul. ${ }^{69}$ Plato, Averroës, Siger, and the comparison that Pico borrowed from Albert thus continued to be interconnected for Nifo at the time that he finished and published his De intellectu. He clearly took very seriously Pico's explication of Plato and also Siger's interpretation of Averroës in order to reconcile various philosophers. Nonetheless, Nifo rejected both that explication of Plato and also Siger's interpretation of Averroës.

Obviously Pico's own understanding of Siger merits more detailed attention for the light that it will throw both on Pico's own thought and on Nifo's own interpretation of Siger and Averroës. Much remains to be done to establish in a more definitive manner the impact of medieval philosophy on what we call "Renaissance Aristotelianism."70

Duke University

69. Nifo De intellectu 1.3.26, fol. 35va-b. See Nifo Expositio Destructio destructionum 1 doubt 8 , fol. 9rb, and 1 doubt 23, fol. 23rb. Nifo also refers here back to his earlier discussion of Averroës in De intellectu 1.1.14, fol. 21va-b, where he also cites his Expositio Destructio destructionum 1 doubts 23-24.

70. After the completion of this study, the recent monograph by Fernand Roulier, Jean Pic de la Mirandole (1463-1494), humaniste, philosophe, et théologien, Bibliothèque Franco Simone 17 (Geneva: Slatkine, 1989), came to my attention. Roulier does allude to Pico's stay at Padua and his connection to Vernia and Nifo. He also refers to Pico's conversation with Nifo regarding Plato (see especially p. 369, n. 69; pp. 407 and 409). Unfortunately, he seems unaware of changes in Vernia's and Nifo's positions and ignores most recent scholarship in English dealing with Padua, Vernia, and Nifo. I should like to note that different versions of this paper were read to the University Seminar on the Renaissance, Columbia University, on 6 March 1984, and to a meeting of the Society for Medieval and Renaissance Philosophy at San Diego on 28 March 1992. It is my intention to return to Nifo on Pico, Siger, and Simplicius on another occasion. I must express once again my gratitude to the Duke University Research Council for grants for travel and microfilming that made this study possible. 